\title{
Plenipotentiary FOR CONTROL OF PROCESSING of PERSONAL DATA IN The Central ANTICORRUPTION BUREAU AND HIS GUARANTEE FUNCTION
}

\author{
PEŁNOMOCNIK DO SPRAW KONTROLI \\ PRZETWARZANIA DANYCH OSOBOWYCH \\ w Centralnym Biurze Antykorupcyjnym \\ I JEGO FUNKCJA GWARANCYJNA
}

\begin{abstract}
The Central Anticorruption Bureau as a special service of the Polish state, constitutes a new quality in public life. His actions may pose a threat to the constitutional rights of the individual. In order to monitor the process of protection of personal data in this institution, he was appointed in the Office of the Plenipotentiary for control of processing of personal data at the CBA. None of the Polish special services has such an institution.

\section{STRESZCZENIE}

Centralne Biuro Antykorupcyjne (CBA) jako służba specjalna państwa polskiego stanowi nową jakość w życiu publicznym. Jego działania mogą stanowić zagrożenie dla konstytucyjnych praw jednostki. W celu monitorowania procesu ochrony danych osobowych w tej instytucji powołany został w CBA pełnomocnik ds. kontroli przetwarzania danych osobowych. Żadna z polskich służb specjalnych nie posiada takiej instytucji.

KEYWORDs: Plenipotentiary for control of processing of personal data, Personal data, Central Anticorruption Bureau, corruption, crime, state security, constitutional rights and freedoms, special services, penal sanctions
\end{abstract}


SŁOWA KLUCzOWE: petnomocnik ds. kontroli przetwarzania danych osobowych, dane osobowe, Centralne Biuro Antykorupcyjne, korupcja, przestępczość, bezpieczeństwo państwa, konstytucyjne prawa $i$ wolności, stużby specjalne, sankcje karne

\section{WPROWADZENIE}

Utworzenie w 2006 r. Centralnego Biura Antykorupcyjnego było swoistym fenomenem $\mathrm{w}$ polskim życiu publicznym (Ustawa $\mathrm{z}$ dnia 9 czerwca 2006 r. o Centralnym Biurze Antykorupcyjnym, Dz.U. z 2017 r. poz. 1993). Powstała instytucja wielu formatów, która w polskiej tradycji ścigania przestępczości dotąd nie miała precedensu. Stworzenie nowej służby specjalnej ukierunkowanej na zwalczanie korupcji oznaczało dostrzeżenie przez klasę polityczną całego spektrum zjawisk korupcyjnych (w tym także niepenalizowanych) i realnego zagrożenia, jakie stanowią dla bezpieczeństwa państwa. Centralne Biuro Antykorupcyjne stanowiło jakościowo nowy instrument walki z przestępczością, ponieważ powołane zostało jako pierwsza polska służba specjalna umocowana do walki z pewną (dość wąsko) określoną kategorią przestępczości (Chodak, 2013). Jednocześnie ustawodawca wyposażając tą służbę oprócz uprawnień operacyjnych i dochodzeniowo-śledczych również w uprawnienia kontrolne i edukacyjne, starał się stworzyć jak najszerszą możliwość prowadzenia operacji antykorupcyjnych zgodnie z zasadami prewencji ogólnej (Bożek, 2007). Nawet w kategorii badania compliance oraz weryfikacji oświadczeń majątkowych niektórych osób publicznych (Lizak, 2015).

Te szczególne uprawnienia w połączeniu z głośnymi nazwiskami będącymi celem działań Biura spowodowały, iż stało się ono przedmiotem ostrej krytyki klasy politycznej. Działaniom funkcjonariuszy CBA zarzucano upolitycznienie i nagminne łamanie praw obywatelskich. Ustawa o CBA została skierowana do Trybunału Konstytucyjnego (TK), który wyrokiem z 23 czerwca 2009 r., sygn. K 54/07, stwierdził konieczność wprowadzenia nadzoru nad przetwarzaniem danych osobowych przez Centralne Biuro Antykorupcyjne. Na skutek wyroku TK ustawodawca znowelizował ustawę o CBA, czego bezpośrednim skutkiem było powstanie w CBA instytucji pełnomocnika ds. kontroli przetwarzania danych osobowych, który pełni jednocześnie funkcję administratora bezpieczeństwa informacji w służbie (Ustawa z dnia 5 sierp- 
nia 2010 r. o zmianie ustawy o Centralnym Biurze Antykorupcyjnym oraz ustawy o sporcie, Dz.U. z 2010 r. nr 151, poz. 1014). Paradoksalnie wyrok ten pozwolił udoskonalić i zmodernizować działający w CBA system ochrony danych osobowych. Funkcjonowanie tej instytucji należy ocenić w kontekście odpowiedzi na pytania dotyczące realizacji funkcji gwarancyjnej dla ochrony danych osobowych obywateli: czy instytucja ta w sposób realny daje gwarancje ochrony danych osobowych? Czy spełnia standardy konstytucyjne?

Istniejące regulacje prawne (art. 22 ust. 1 ustawy o Centralnym Biurze Antykorupcyjnym) zezwalają CBA w zakresie swoich właściwości uzyskiwać informacje, w tym także niejawne, gromadzić je, sprawdzać i przetwarzać. Zgoda wyrażona przez ustawodawcę rozciąga się również na dane osobowe sensytywne w rozumieniu art. 27 ust. 1 Ustawy z dnia 29 sierpnia 1997 r. o ochronie danych osobowych, bez wiedzy i zgody osób, których dotyczą (art. 22a. ust. 1 Ustawy o Centralnym Biurze Antykorupcyjnym). Jedynym warunkiem zgodnie $\mathrm{z}$ zasadą celowości przetwarzania danych osobowych (zbieranie danych osobowych powinno być dokonywane dla oznaczonych, zgodnych z prawem celów i niepoddawane dalszemu przetwarzaniu niezgodnemu z tymi celami) oraz zasadą adekwatności (administrator powinien przetwarzać tylko takiego rodzaju dane o tylko o takiej treści, które są niezbędne ze względu na cel ich zbierania; relewantność danych powinna być oceniania najpóźniej w momencie ich zbierania) jest wykonywanie zadań przez Centralne Biuro Antykorupcyjne określonych w art. 2 ust. 1 ustawy o CBA. Biuro dla realizacji swoich zadań może nieodpłatnie uzyskiwać dane ze zbiorów danych prowadzonych przez organy władzy publicznej oraz państwowe lub samorządowe jednostki organizacyjne (art. 22a ust. 2 Ustawy o Centralnym Biurze Antykorupcyjnym).

Warta podkreślenia jest prawna możliwość przetwarzania danych osobowych bez wiedzy i zgody osób, których dotyczą. Ta istotna ingerencja w system praw i wolności osobowych wymaga szczególnych gwarancji zapewnionych m.in. przez sprawne instytucje kontroli wewnętrznej.

Ochrona danych osobowych w Centralnym Biurze Antykorupcyjnym oparta została na dwóch zasadach:

1. Odpowiedzialności administratora danych osobowych, jakim pozostaje Szef Centralnego Biura Antykorupcyjnego. 
2. Autonomicznego systemu nadzoru opartego na aparacie kontroli pełnomocnika ds. kontroli przetwarzania przez Centralne Biuro Antykorupcyjne danych osobowych (dalej: pełnomocnik ds. danych osobowych), którego autonomiczność jest zagwarantowana przez Ustawę o Centralnym Biurze Antykorupcyjnym, m.in. poprzez szczególny tryb odwołania $\mathrm{z}$ pełnionej funkcji.

Wspomniany powyżej pełnomocnik jest szczególną instytucją, której nie posiadają inne służby (np. ABW, SKW, AW, Policja, Służba Więzienna) i jest specjalnie umocowany nie tylko w strukturze organizacji Biura, ale także w systemie służb specjalnych, stanowiąc niejako modelowy przykład niezależności służb od świata polityki i dając realną możliwość przestrzegania przez CBA konstytucyjnych praw i wolności obywatelskich.

Pełnomocnik ds. danych osobowych w Centralnym Biurze Antykorupcyjnym nie jest oczywiście tożsamy z instytucją pełnomocnika ds. ochrony informacji niejawnych. Przede wszystkim działają oni na podstawie odmiennych aktów prawnych (Ustawa o ochronie informacji niejawnych oraz Ustawa o Centralnym Biurze Antykorupcyjnym), ale przede wszystkim pełnomocnik ds. danych osobowych w CBA sprawuje nadzór nad zgodnością przetwarzania danych osobowych gromadzonych przez CBA z przepisami Ustawy o ochronie danych osobowych. Zaś pełnomocnik ds. ochrony informacji niejawnych, który podlega bezpośrednio kierownikowi jednostki organizacyjnej, odpowiada za zapewnienie przestrzegania przepisów o ochronie informacji niejawnych. To właśnie specyficzna forma podległości pełnomocnika ds. danych osobowych jest jednym z elementów kształtujących jego niezależność i gwarantujących efektywność pełnienia przez niego swojej funkcji.

Szef Centralnego Biura Antykorupcyjnego oprócz swojej funkcji zasadniczej jest także administratorem danych osobowych (ADO) w CBA. Pełnomocnik ds. danych osobowych jest powoływany przez Szefa CBA spośród podległych mu funkcjonariuszy. Natomiast jego odwołanie może nastąpić za zgodą Prezesa Rady Ministrów, po zasięgnięciu opinii Sejmowej Komisji ds. Służb Specjalnych. Pełnomocnik realizuje niezwłocznie obowiązek informacyjny w przypadku naruszenia przepisów ustawy oraz przepisów o ochronie danych osobowych wobec Prezesa Rady Ministrów 
i Szefa CBA. Jego obowiązkiem jest coroczne przedstawianie sprawozdania Prezesowi Rady Ministrów, Sejmowej Komisji ds. Służb Specjalnych oraz Generalnemu Inspektorowi Ochrony Danych Osobowych ze stanu ochrony danych osobowych w CBA oraz wszystkich przypadków naruszenia tych przepisów.

Pełnomocnik ds. danych osobowych (art. 22b ust. 1 ustawy o CBA) posiada uprawnienia i wykonuje obowiązki administratora bezpieczeństwa informacji (ABI) (art. 22b ust. 2 ustawy o CBA). Ustawa ta daje mu zresztą szerokie uprawnienia, odpowiadające spektrum jego zadań i specyfice działania służby. Należą do nich:

- prowadzenie rzetelnej obiektywnej i niezależnej kontroli prawidłowości przetwarzania danych osobowych, a w szczególności ich przechowywania, usuwania i weryfikacji,

- wgląd do wszelkich dokumentów związanych z przeprowadzaną kontrolą,

- swobodny dostęp wszystkich kontrolowanych do pomieszczeń,

- żądanie pisemnych wyjaśnień od kierowników kontrolowanych jednostek.

Pełnomocnik ds. danych osobowych działa również podstawie Ustawy o ochronie danych osobowych (art. 36a ust. 2 Ustawy o ochronie danych osobowych), która zobowiązuje go do:

- sprawdzania zgodności przetwarzania danych osobowych z przepisami o ochronie danych osobowych,

- nadzorowania opracowywania i aktualizacji dokumentacji,

- zapoznawania z przepisami osób upoważnionych do przetwarzania danych osobowych,

- prowadzenia rejestru zbiorów danych osobowych.

$\mathrm{Z}$ istniejącym stanowiskiem łączy się wiele uprawnień, które pełnią rolę wykonawczą wobec jego kompetencji ustawowych, nie tylko na podstawie zapisów ustawowych, również przepisów wewnętrznych CBA, łączących funkcję pełnomocnika i administratora bezpieczeństwa informacji (Polityka bezpieczeństwa ochrony danych osobowych w Centralnym Biurze Antykorupcyjnym - Załącznik Nr 1 do Zarządzenia Nr 18/16 Szefa Centralnego Biura Antykorupcyjnego z dnia 1 lipca 2016 r. w sprawie systemu ochrony danych osobowych w Centralnym Biurze Antykorupcyjnym). Należą do nich: 
- wydawanie pisemnych poleceń usunięcia stwierdzonych uchybień w zakresie prawidłowości przetwarzania danych osobowych,

- prowadzenie działań zmierzających do wyjaśnienia okoliczności naruszenia przepisów w zakresie przetwarzania danych osobowych w CBA,

- wydawanie zaleceń dotyczących usprawnienia systemu ochrony danych osobowych w CBA,

- inicjowanie zmian w polityce bezpieczeństwa ochrony danych osobowych w CBA w celu zapewnienia właściwego poziomu ochrony ich przetwarzania,

- nadzorowanie, opracowanie i aktualizacja dokumentacji przetwarzania danych osobowych,

- prowadzenie wykazu zbiorów danych osobowych przetwarzanych w CBA,

- prowadzenie rejestru zbiorów danych osobowych,

- prowadzenie szkoleń z zakresu ochrony danych osobowych dla osób upoważnionych do przetwarzania danych osobowych,

- sprawowanie nadzoru nad realizacją obowiązku prowadzenia ewidencji osób upoważnionych do przetwarzania danych osobowych,

- dokonywanie okresowej analizy zagrożeń dla bezpieczeństwa danych osobowych oraz zlecaniu jej przeprowadzenia dla zbiorów przetwarzanych danych osobowych,

- realizowanie procedur związanych ze zgłaszaniem Generalnemu Inspektorowi Ochrony Danych Osobowych zbiorów danych osobowych przetwarzanych w CBA podlegających rejestracji,

- udzielanie osobom uprawnionym informacji o zasadach i sposobach przetwarzania danych osobowych w CBA.

Pełnomocnik, jak wynika z powyższego zestawienia, pełni rolę kluczową w systemie ochrony danych osobowych w CBA, na który składają się wg kolejności:

1. Administrator danych osobowych (ADO) - Szef CBA. Podejmuje on decyzje o celach i środkach przetwarzania danych osobowych z uwzględnieniem konieczności właściwej realizacji zadań CBA oraz aktualnych technik zabezpieczenia danych. 
2. Administrator bezpieczeństwa informacji (ABI) - pełnomocnik ds. ochrony danych osobowych.

3. Lokalny administrator danych osobowych (LADO) - kierownik jednostki organizacyjnej CBA. Na podstawie upoważnienia Szefa CBA wykonuje on w podległej sobie jednostce zadania administratora danych osobowych. Ponadto wykonuje polecenia $\mathrm{ABI}$ - pełnomocnika.

4. Administrator systemu (AZ) - kierownik jednostki organizacyjnej odpowiedzialnej za zapewnienie ciągłości działania systemów i sieci teleinformatycznych. Jego naczelnym zadaniem jest zapewnienie ciągłości działania systemów i sieci teleinformatycznych służących do przetwarzania danych osobowych.

5. ABZ - administratorzy bezpieczeństwa zbiorów w poszczególnych jednostkach organizacyjnych CBA. Wdrażają i nadzorują oni przestrzeganie instrukcji oraz polityki bezpieczeństwa ochrony danych osobowych. Niezależnie od powyższego wykonują polecenia ABI.

6. Funkcjonariusz (pracownik) CBA posiadający uprawnienia do przetwarzania danych osobowych w Centralnym Biurze Antykorupcyjnym.

Ten system jest komplementarny i jego poszczególne składowe są dopasowane do rodzaju zadań związanych z przetwarzaniem danych osobowych przez poszczególnych funkcjonariuszy CBA. Każdy z wymienionych elementów powołany jest przede wszystkim do respektowania głównych zasad przetwarzania danych osobowych wg art. 26 Ustawy o ochronie danych osobowych, tj.:

- zasady celowości,

- zasady legalności,

- zasady adekwatności,

- zasady merytorycznej poprawności,

- zasady ograniczenia czasowego.

Realizacja każdej z powyższych zasad jest obowiązkiem każdej osoby w CBA, która dokonuje przetwarzania danych. Z punktu widzenia pełnomocnika ds. danych osobowych priorytetem w jego działaniach pozostaje zasada ograniczenia czasowego, czyli kontrola realizacji obowiązku 
przechowania danych w postaci umożliwiającej identyfikację osób, których dane dotyczą, nie dłużej niż jest to niezbędne do osiągnięcia celu przetwarzania. Po osiągnięciu celu dane powinny zostać usunięte, zanonimizowane lub też przekazane podmiotowi uprawnionemu ustawowo do ich przejęcia od administratora m.in. archiwum państwowemu. Działania kontrolne przeprowadzane przez pełnomocnika ds. danych osobowych pozwalają na aktualną ocenę realizacji tego obowiązku przez funkcjonariuszy i pracowników CBA.

Oczywiście nie tylko pełnomocnik, ale także funkcjonariusze oraz pracownicy cywilni CBA podlegają odpowiedzialności zarówno karnej, jak i dyscyplinarnej opartej na przepisach karnych zarówno Ustawy o ochronie danych osobowych, jak i Kodeksu karnego. W przypadku Ustawy o ochronie danych osobowych mają zastosowanie przepisy art. 49 dotyczące nieuprawnionego przetwarzania danych osobowych, a także art. 51 i 52 penalizujące nieuprawniony dostęp do danych osobowych oraz ich niewłaściwe zabezpieczenie. Zastosowanie mogą również znaleźć art. 53 i 54 traktujące o sankcji karnej za niedopełnienie obowiązku rejestracyjnego zbioru danych, jak również realizacji obowiązku informacyjnego. Karalne jest również utrudnianie czynności kontrolnych na podstawie art. 54a.

Odpowiedzialność karna funkcjonariuszy i pracowników cywilnych CBA wynika także z przepisów Kodeksu karnego (kk). Ma tutaj zastosowanie art. $266 \mathrm{kk}$ penalizujący nieuprawnione ujawnienie tajemnicy służbowej i zawodowej, jak również art. 268 - przewidujący karę za utrudnienie lub udaremnienie korzystania $z$ informacji oraz art. 269 dotyczący odpowiedzialności za niszczenie danych informatycznych, czyli sabotaż komputerowy.

Negatywne konsekwencje związane $z$ naruszeniem ochrony prawnej danych osobowych mogą również wynikać z art. 24 Kodeksu cywilnego normującego ochronę dóbr osobistych. Dane osobowe należą do kategorii dóbr chronionych, których naruszenie może skutkować procesem cywilnym.

Należy wspomnieć również o treści art. 106 i 107 Ustawy o Centralnym Biurze Antykorupcyjnym normujących zasady odpowiedzialności dyscyplinarnej funkcjonariuszy. Ponoszą oni odpowiedzialność dyscyplinarną za popełnione przestępstwa i wykroczenia, niezależnie od odpowiedzialności karnej za swoje postępowanie. 


\section{Podsumowanie}

Centralne Biuro Antykorupcyjne jako nowoczesna służba specjalna państwa polskiego musi spełniać nie tylko standardy wyznaczone dla służb specjalnych i instytucji policyjnych, które zapewniają efektywność realizacji ich kompetencji ustawowych. Z uwagi na represyjny charakter działań służby jej funkcjonariusze zobligowani są do zachowania szczególnej staranności w swoim postępowaniu w zakresie przestrzegania podstawowych uprawnień konstytucyjnych obywateli. Instytucja pełnomocnika ds. ochrony danych osobowych jest nie tylko instrumentem autokontroli CBA w zakresie przestrzegania danych osobowych. Zapewnia także uszczelnienie systemu ochrony i - co szczególnie cenne - motywuje instytucję do nieustannego progresu w zakresie kultury ochrony danych osobowych. I to rozumianej w szerokim zakresie - jako działania kontrolne, projekty aktów prawnych, jak i profilaktyka rozumiana nie tylko jako prowadzenie szkoleń, ale także innych działań, takich jak weryfikacja bieżących zasobów BCA i nadzorowanie usuwania zbędnych danych.

Szeroka autonomia pełnomocnika i szczególny sposób jego odwołania stanowi jeden z istotnych elementów gwarancyjnych niezawisłość jego działań. W tym kontekście można stwierdzić, że pełnomocnik realizuje funkcję gwarancyjną ochrony danych osobowych. Podobną uwagę należy odnieść do realizacji konstytucyjnych praw obywatelskich w zakresie ochrony prywatności, w tym danych osobowych. Należy jednak podnieść, iż ochrona ta byłaby pełniejsza, gdyby przepisy Ustawy o Centralnym Biurze Antykorupcyjnym pozwalały na powoływanie pełnomocnika także wśród innych osób, również spoza funkcjonariuszy CBA (mógłby je np. wskazywać Prezes Rady Ministrów lub właściwy minister ds. koordynacji służb specjalnych). Taki mechanizm mógłby skutecznie wyeliminować podejrzenia o ewentualny konflikt interesów, które są nieuniknione w sytuacji, gdy powoływany pełnomocnik jest funkcjonariuszem CBA i podlega formalnie Szefowi Centralnego Biura Antykorupcyjnego (poza zakresem ochrony danych osobowych). Zatem sposób realizacji funkcji zawsze musi być zgodny z demokratycznym charakterem państwa prawa. Nie ma w nim bowiem sprzeczności między interesem jednostki a interesem państwa, tj. ogółu obywateli. Istnieć bowiem będą tylko okoliczności przewidziane w ustawie, w którym 
interes ogółu ma pierwszeństwo przed interesem jednostki i w niezbędnym zakresie ogranicza jej prawa.

Te ograniczenia są konieczne, wskazuje na to zakres zadań realizowany przez CBA, mieszczący się w katalogu dóbr konstytucyjnie gwarantowanych. Podstawa prawna, cel i zakres tego ograniczenia określony jest w przepisach rangi ustawowej. Biuro jako instytucja posiada gwarancje bezpieczeństwa w postaci niezwłocznego usunięcia zbędnych danych. Jest to kolejny mechanizm gwarancyjny. Pamiętać również należy o tym, iż stosowane środki ingerencji odpowiadają zasadzie proporcjonalności.

Centralne Biuro Antykorupcyjne posiada zinstytucjonalizowany system ochrony danych osobowych, właściwie umocowany w przepisach prawnych, posiadający realne możliwości ochrony danych.

\section{Literatura}

Bart, J., Fajgielski, P., Markiewicz, R. (2011). Ochrona danych osobowych. Komentarz. Warszawa: Wolters Kluwer Polska. ISBN 9788326414817.

Bill, J. (2012). Obszary, mechanizmy oraz skala przestęstw korupcyjnych $w \dot{z} y c i u$ publicznym i gospodarczym oraz kierunki ich ewaluacji. W: J. Kosiński, K. Krak, A. Koman (red.), Korupcja i antykorupcja. Wybrane zagadnienia. Część III, Warszawa: Centralne Biuro Antykorupcyjne. ISBN 9788362455683.

Bożek, M. (2007). Charakter zadań Centralnego Biura Antykorupcyjnego w świetle ustawy z dnia 9 czerwca 2006 r. o Centralnym Biurze Antykorupcyjnym. W: Z. Bielecki, J. Szafrański (red.), Zwalczanie przestępczości korupcyjnej w Polsce, materiały pokonferencyjne, Szczytno: Wydział Wydawnictw i Poligrafii Wyższej Szkoły Policji. ISBN 9788374621366.

Bożek, M. (2013). Sejmowa kontrola działalności służb specjalnych i jej ograniczenia wynikajace $z$ ustaw kompetencyjnych: zarys problemu na tle uwarunkowań normatywnych, „Studia Iuridica Lublinensia” nr 20, Lublin. ISSN 1731-6375.

Chodak, P. (2013). Korupcja w siłach zbrojnych Rzeczypospolitej Polskiej, Warszawa: Przegląd Antykorupcyjny CBA. ISBN 2083-7127.

Chodak, P. (2013). Zgoda społeczeństwa za niewielkie przestępstwa korupcyjne, „Journal of Modern Science" 3/18, s. 191-210. ISSN 1734-2031.

Ciesielczyk, M. (2005). Przeciw korupcji, Tarnów: Witek-Druk. ISBN 8387183334.

Gryz, J. (2010). Zarys podstaw teorii bezpieczeństwa, Warszawa: Akademia Obrony Narodowej. ISBN 9788375231281. 
Heidenheimer, A.J., Johston, M. (red.). (2002). Political corruption; Readings Concepts and Contexts, New Jork: New Brunswick, Transaction Publishers. ISBN 9780765807618.

Holger, M.A. (red.). (2006), Europa bez korupcji. Studium przypadków. Kazusy polsko-niemiecko-belgijskie. Podręcznik dobrych praktyk, Warszawa: Ministerstwo Spraw Wewnętrznych i Administracji. ISBN 9788361647010.

Karklins, R. (2009). Wszystkiemu winien system. Korupcja $w$ krajach postkomunistycznych, Warszawa: Wydawnictwo Sic!. ISBN 9788360457672.

Lizak, R. (2015). Rola Centralnego Biura Antykorupcyjnego jako komórki compliance państwa, „Przegląd Antykorupcyjny. Czasopismo Centralnego Biura Antykorupcyjnego" nr 1(5), Warszawa. ISSN 2083-7127.

Marszałek, M., Gilen, A., Wiśniewski, B. (2009). Stużby Mundurowe w systemie bezpieczeństwa EURO 2012, konferencja naukowa, Sieradz: Prof-Art Agencja Reklamowo-Wydawnicza. ISBN 9788389954862.

Mądrzejowski, W. (2007). Środowiska zagrożone korupcją. W: Z. Bielecki, J. Szafrański (red.), Zwalczanie przestępczości korupcyjnej w Polsce, materiały pokonferencyjne, Szczytno: Wydział Wydawnictw i Poligrafii Wyższej Szkoły Policji. ISBN 9788374621366.

Palka, P., Reut, M. (1999). Korupcja w nowym Kodeksie Karnym, Kraków: Zakamycze. ISBN 8388114204.

Pokruszyński, W. (2008). Bezpieczeństwo Narodowe u progu XXI wieku, „Zeszyty naukowe AON" nr 1/70, Warszawa: Akademia Sztuki Wojennej. ISSN 0867-2245.

Pokruszyński, W. (2010). Teoretyczne aspekty bezpieczeństwa, Józefów: Wyższa Szkoła Gospodarki Euroregionalnej im. Alcide de Gasperi. ISBN 9788393010233.

Siemaszko, A. Gruszczyńska, B., Marczewski, M. (2012). Społeczna percepcja zagrożeń korupcyjnych $w$ Polsce. W: J. Kosiński, K. Krak, A. Koman (red.), Korucja i Antykorupcja. Wybrane zagadnienia. Część III, Warszawa: Centralne Biuro Antykorupcyjne. ISBN 9788362455683.

Woźnicki, D. (2007). Rozwiązania systemowe jako skuteczne narzędzie zwalczania przestępczości korupcyjnej. W: Z. Bielecki, J. Szafrański (red.), Zwalczanie przestępczości korupcyjnej w Polsce, materiały pokonferencyjne, Szczytno: Wydział Wydawnictw i Poligrafii Wyższej Szkoły Policji. ISBN 9788374621366. 


\section{Akty prawne}

Polityka bezpieczeństwa ochrony danych osobowych w Centralnym Biurze Antykorupcyjnym - Załącznik Nr 1 do Zarządzenia Nr 18/16 Szefa Centralnego Biura Antykorupcyjnego z dnia 1 lipca 2016 r. w sprawie systemu ochrony danych osobowych w Centralnym Biurze Antykorupcyjnym.

Ustawa z dnia 23 kwietnia 1964 r. Kodeks cywilny (Dz.U. z 2017 r. poz. 459, 933, 1132).

Ustawa z dnia 6 czerwca 1997 r. Kodeks karny (Dz.U. z 2017 r. poz. 2204).

Ustawa z dnia 29 sierpnia 1997 r. o ochronie danych osobowych (Dz.U. z 2016 r. poz. 922).

Ustawa z dnia 9 czerwca 2006 r. o Centralnym Biurze Antykorupcyjnym (Dz.U. z 2017 r. poz. 1993).

Ustawa $\mathrm{z}$ dnia 5 sierpnia 2010 r. o zmianie ustawy o Centralnym Biurze Antykorupcyjnym oraz ustawy o sporcie (Dz.U. z 2010 r. nr 151, poz. 1014).

Ustawa z dnia 5 sierpnia 2010 r. o ochronie informacji niejawnych (Dz.U. z 2016 r. poz. 1167, 1948, z 2017 r. poz. 935).

\section{Źródła internetowe}

Bożek, M. Miejsce i rola Centralnego Biura Antykorupcyjnego w systemie organów państwowych na tle obowiązującego ustawodawstwa, www.antykorupcja.gov.pl (dostęp: 5.01.2018).

www.antykorupcja.edu.gov.pl (dostęp: 23.12.2017).

www.abw.gov.pl (dostęp: 23.12.2017).

www.aw.gov.pl (dostęp: 23.12.2017).

www.cba.gov.pl (dostęp: 23.12.2017).

www.giodo.gov.pl (dostęp: 23.12.2017).

www.policja.gov.pl (dostęp: 23.12.2017).

www.sw.gov.pl (dostęp: 23.12.2017).

www.trybunal.gov.pl (dostęp: 23.12.2017). 